\section{MICROSCOPIC STAINS}

\section{\& Reagents}

\author{
Azocarmine \\ Brazillin \\ Brilliant Cresyl Blue \\ Carmine \\ Carminic Acid \\ Cedarwood Oil \\ Cresyl Fast Violet \\ Field's Stain \\ Giemsa Stain \\ Haematoxylin \\ Janus Green \\ Lacmoid \\ Leishman Stain \\ May-Grunwald Stain \\ Night Blue \\ Nile Blue, etc. \\ Stains \& Reagents for \\ Fluorescence Microscopy. \\ Price List on application
}

\section{EDWARD GURR, LTD.}

42 UPPER RICHMOND ROAD

EAST SHEEN, LONDON, S.W.14

Telephone: Prospect 7606 \& 805I

Cables: Micromlabs, London

UNIFORM HITH QUNLTTY, RELABRLITY

Nowready: "Practical Manual of Medical and Blological Staining Techniques"

350 pages, price $26 s$. post free.

\section{The British Journal of Nutrition \\ $\&$ \\ The Proceedings of \\ The Nutrition Society}

Are now published in separate parts (4 parts of the fournal and 2 parts of Proceedings) and may be obtained at a combined subscription rate of $£ 6$ net per volume. The price for single issues of either publication is 30s., postage extra.

Orders may be sent to your Bookseller or placed direct with the Publishers the

CAMBRIDGE UNIVERSITY PRESS Bentley House 200 Euston Road, London, N.W.r

The fournal of Agricultural Science is issued in quarterly parts of about 120 pages with plates and figures, four parts constituting a volume.

Volumes XVI-XX (1926-1930) are out of print. Quotations can be given for other back volumes and parts.

Quotations can also be given for buckram binding cases. (Suspended.)

Papers for publication should be typewritten or written in a very legible hand, and may be sent to DR J. HAMmond, School of Agriculture, Cambridge, or to the associate Editors. Other communications should be addressed to the University Press, Cambridge.

If Plates in excess of one per 24 pages of text are submitted the author may be asked to bear the cost of such Plates.

Bibliography should be given under the heading of "References" in the following form:

Surname of authors (in alphabetical order), initials, date of publication (in brackets), title of Journal (abbreviated according to the World List of Scientific Periodicals), volume and pages of reference. In the text a reference should be quoted by the author's name and date (in brackets).

All names of Journals and books should be in italics.

Contributors will receive twenty-five copies of their papers free.

The subscription price for each volume after volume 42 , payable in advance, is 6os. net per volume (post free); single numbers 20s. net. Subscriptions may be sent to any bookseller, or to The Cambridge University Press, Bentley House, 200 Euston Road, London, N.W. r.

Subscription price in the U.S.A. is \$10.50 per volume; single numbers \$3.50. Enquiries should be addressed to the Cambridge University Press American Branch, 32 East 57th Street, New York, 22. 


\section{CONTENTS}

Chinloy, T., InNes, R. F. and Finney, D. J. An example of fractional replication in an experiment on sugar cane manuring. (With One Text-figure

Henderson, A. E. Fleece development and wool growth on the Romney lamb. (With Plates 1 and 2 and Twenty-one Text-figures) . .

ChANDA, $\mathbf{R}$. The partition of carotenoids and vitamin $\mathrm{A}$ in the colostrum and milk of the cow and the goat. (With Five Text-figures) . $\quad 54$

PhILlips, R. Meat production from cattle in West Wales 1943-8 . $\quad 72$

PAtTERSON, H. D. The analysis of the results of a rotation experiment on the use of straw and fertilizers . . . . . . .

Jewitr, T. N. Seasonal variations in the composition of young cotton leaves in the Sudan Gezira . . . . . . . . $\quad . \quad 89$

DAMmERS, J. The importance of vitamin $\mathbf{B}_{12}$ for pig feeding . $\quad$. $\quad$ - 92

Nicholson, H. H. and FIRTH, D. H. The effect of ground water-level on the performance and yield of some common crops. (With Plate 3 and Ten Text-figures

Bell G. D. H. and SaCHS, LeO. Investigations in the Triticinae. II. The cytology and fertility of intergeneric and interspecific $F_{1}$ hybrids and their derived amphidiploids. (With Plate 4) . . . . .

Bolton, W. Observations on the vitamin metabolism of the common fowl. III. The effects of oestradiol dipropionate, testosterone propionate and progesterone injections in immature pullets on the riboflavin content of the magnum . . . . . . . .

Bolron, W. Observations on the vitamin metabolism of the common fowl. IV. Free and combined riboflavin in the magnum and liver of the laying hen fed a diet high in riboflavin . . . . .

WienER, G. Breed structure in the pedigree Ayrshire cattle population in Great Britain. (With Two Text-figures) . 